\section{Age Cohort Influences Brand Recognition, Awareness, and Likelihood to Buy Vegetable and Herb Transplants}

\author{
Bridget K. Behe ${ }^{1}$ \\ Department of Horticulture, Michigan State University, 1066 Bogue Street, \\ East Lansing, MI 48824 \\ Patricia Huddleston \\ Advertising and Public Relations, Michigan State University, 404 Wilson \\ Road, East Lansing, MI 48824
}

\author{
Lynnell Sage \\ Department of Horticulture, Michigan State University, 1066 Bogue Street, \\ East Lansing, MI 48824
}

Additional index words. Capsicum annuum, consumer, conjoint analysis, green industry, Ocimum basilicum, Petroselinum crispum, Solanum lycopersicum, survey

\begin{abstract}
Marketers invest nearly $8 \%$ of their advertising budget on in-store marketing because $>70 \%$ of all buying decisions are made at the point of purchase. Older consumers, especially Baby Boomers (typically classified as persons born from 1950 to 1965) have long been considered a core target market for horticultural products. However, some industry concerns have arisen with regard to the lack of purchasing among younger age cohorts, especially Gen X (born 1966-77) and Gen Y (born 1978-90). Brands help to create the perception of added value while also differentiating products from competitors. Often, brands are one of a few pieces of information consumers use to make product choices. We conducted an online survey in May 2014 to investigate the role of age cohort and brand recognition on the likely to buy (LTB) rating of two herb and two vegetable transplants. We showed study participants images of 16 plants, varying the container color (white, green, and yellow), plant type (basil, parsley, tomato, and pepper), plant brand (generic and three national brands), and price. About equal numbers from three age cohorts (Boomers, Gen X, and Gen Y) were represented in the sample of 566 plant purchasers. We observed that more Boomers had seen (recognized) Brand $P$, whereas more Gen $X$ and Gen Y participants had seen Brand L. Subjects who had seen the plant brands before the study had a higher mean LTB rating for branded plants compared with those who had not seen the plant brands before the study. Furthermore, both Gen X and Gen Y were more LTB branded plants compared with Boomers. In the conjoint analysis, we found that plant type was the most important product attribute. Price and brand were similarly important but also less important than plant type. All three attributes were more important than container color. Having no brand on the container detracted $\$ 0.20$ from the perceived value of the plant while the brands added up to $\$ 0.15$ to the perceived plant value. Future marketing strategies which include branded plants at the point of purchase likely will increase perceived product value and LTB, especially among younger consumers.
\end{abstract}

Received for publication 30 Oct. 2015. Accepted for publication 23 Dec. 2015.

Federal funds were matched with state funds in the U.S. Department of Agriculture (USDA) FederalState Marketing Improvement Program to fund this research. This project was supported by the USDA National Food and Agriculture, Hatch Project Number MICL 02085, and by Michigan State University AgBioResearch.

We thank Masterpiece Flower Co. and Dramm Corp. for their generous donations to facilitate this research and Marlene Cameron for adaptation of the images. We also thank Michelle Quigley with the Statistical Consulting Center in the College of Agriculture and Natural Resources Biometry Group at Michigan State University for her advice on the statistical analyses performed in this study. ${ }^{1}$ Corresponding author. E-mail: behe@msu.edu.

With a slowing of plant sales growth (Hodges et al., 2009), competition among companies for consumers' dollars has heightened. Sluggish demand indicates a maturing market, and an influx of brands is likely to occur at that time in an effort to differentiate products from competitors and enhance the perceived product value (Kotler and Keller, 2009). Branding helps to create the perception of added value and/or distinguishes a company's products from competitors'. Differentiation and enhancing perceived value through branding may be fruitful actions for the company striving to increase sales. In horticulture, anecdotal evidence suggests that plant branding appears to be more prolific in the 21st century.

With $>70 \%$ of all buying decisions made at the point of purchase, marketers increased their in-store marketing budgets from $\approx 3 \%$ in 2004 to $\approx 8 \%$ in 2010 (Ståhlberg and Maila, 2012). Marketers also use brands, which facilitate consumers' buying decisions. In the mainstream marketing literature, some evidence suggests that consumers first identify necessary information, before it is cognitively processed, to arrive at a purchase decision (Lin and Chen, 2006; Olson and Jacoby, 1972). Part of that information identified and processed in the purchase decision includes brands. Therefore, it may be important for plant producers and retailers to know which pieces of information at the point of purchase, especially regarding plant brands, influence consumers in their purchase decisions. Although there have been some studies on state or regional brands (Collart et al., 2010; Whery et al., 2007), we still have little information regarding the impact that brands have on consumer perceptions or intentions to purchase plants. Therefore, a better understanding of consumer perceptions of plant branding could help growers, wholesalers, and retailers better manage the branded and generic products they grow, merchandise, and more effectively market products to consumers.

A maturing of the green industry (Hodges et al., 2009) has included weaker product demand particularly among younger aged consumers (Dennis and Behe, 2007). In light of industry concerns about this reduced demand (Hodges et al., 2009) and, at the same time, changing American demographics (Drucker, 2002), a more precise understanding of consumer perceptions of products is helpful to all marketers. Baby Boomers (most typically described as born between 1950 and 1965) have long been a core customer group for live plants (Dennis and Behe, 2007). However, younger age cohorts do not appear to be purchasing plants to the same extent, causing industry concern (Butterfield and Baldwin, 2013). More information is needed about the perceptions, attitudes, and behavior of younger potential customers to attract them to the products offered by horticultural professionals. Do younger potential consumers view the branded herb and vegetable transplants in the same way as Baby Boomers?

\section{Literature Review}

Branding. A brand, as defined by the American Marketing Association (2014), is a "name, term, design, symbol, or any other feature that identifies one seller's good or service as distinct from those of other sellers." A brand name or logo represents an information "chunk" in consumer decision-making (Simon, 1974) because consumers deduce product characteristics partially based on the brand (Jacoby et al., 1971). Brands serve as information cues for consumers, shaping their expectations about product performance (Kapferer, 2012). Prior research showed that brands play a fundamental role in providing cues when consumers make product purchase decisions (Dodds and Monroe, 1985; Dodds et al., 1991; Jacoby et al., 1977; Keller, 2013). Well-crafted and 
well-managed brands give companies an advantage in the marketplace (Holmberg, 2002; Kotler and Keller, 2009) and retailers manipulate displays to draw attention to the brands they want to sell (Chandon et al., 2009; Clement et al., 2013; Drèze et al., 1993).

Research has demonstrated that consumers use very few pieces of information to make a purchase decision (Hansen, 1969; Olson and Jacoby, 1972), most often the information they use are brand and price (Dodds and Monroe, 1985; Jacoby et al., 1974; Kardes et al., 2004; Olson and Jacoby, 1972). Studies suggest that brand recognition influences purchase behavior (Hoyer and Brown, 1990), with recognition of a brand or anything else defined as a mode of attention or "identifying something by its kind (name) and in view of the use to which it could be put" (Krippendorff, 2005, p. 91). Some researchers maintain that brands, which are salient or are on the "top of mind," are the real purchase decision drivers (Chandon and Wansink, 2002; Ehrenberg et al., 1997; Keller, 2013; Nedungadi, 1990). Known brands were more likely selected, regardless of the consumer's quality perception of both known and unknown brands (Hoyer and Brown, 1990). Furthermore, that study showed that when an inexperienced decision-maker was selecting between a known and an unknown brand, she/ he nearly always selected the known brand.

National plant brands have not been as rigorously investigated as state and regional brands. Collart et al. (2010) showed that Texas consumers who shopped for unspecified ornamental plants weekly or monthly had higher state brand awareness than consumers who shopped for plants less often. Consumers who had higher state brand awareness were willing to pay more for branded plants. In their study, the two brands effectively differentiated products creating a price premium of $\approx 10 \%$. In addition, subjects aged $40-55$ years were least likely to be aware of brands, whereas subjects aged $\geq 55$ were willing to pay the least for branded plants. Whery et al. (2007) investigated consumer perceptions of a hypothetical Pennsylvania brand and showed that (Verbena xhybrida Voss 'Tapien Salmon') branded plants in white containers were most preferred and that the container color was a relatively large proportion of the decision to buy $(31.9 \%)$. That finding was opposite that reported in Hall et al. (2010), which showed that half of the study participants were either nondiscriminating or price sensitive in terms of the relative importance of the plant container type.

Demographics. Drucker (2002) wrote that changes in demographics are one of the easiest ways for a business to remain innovative, yet few business managers follow or act on demographic changes. Demographic characteristics are individual attributes, including age, that shape life experiences, which in turn affect how consumers view products and make purchasing decisions. Divisions in the general population into age cohorts vary somewhat by demographer. Baby Boomers (76 million), categorized as those individuals born between 1950 and 1965, comprise one-quarter of the American population and are relatively brand loyal compared with younger age cohorts (Anonymous, 2012). Baby Boomers have bought more floral products compared with Gen X and Gen Y (Dennis and Behe, 2007; Rihn et al., 2012). However, some Boomers are also engaged in vegetable and herb gardening. Butterfield and Baldwin (2013) reported that $28 \%$ of households with persons aged $\geq 55$ engaged in vegetable gardening and $17 \%$ of them engaged in herb gardening.

Gen $X$ and Gen $Y$ are two distinct age cohorts that have been studied because of their increasing influence on the economy (Barrow, 1994; Littrell et al., 2005; Roberts and Manolis, 2000; Silvergleit, 2004). Gen X consists of 44 million people born between 1966 and 1977 (Dunn, 1993). Consumers in this age group reportedly tend to value money, possessions, and the shopping experience more than older generations (Dunn, 1993; Roberts and Manolis, 2000). Members of Gen $\mathrm{X}$ are also characterized as welleducated, self-reliant, and practical (Littrell et al., 2005). Butterfield and Baldwin (2013) reported that $10 \%$ of persons aged $35-44$ engaged in herb gardening, whereas $27 \%$ of them engaged in vegetable gardening.

Gen Y represents 72 million Americans born between 1979 and 1995, who are the most ethnically and culturally diverse age cohort in America today; nearly $25 \%$ of this age group is African American and 18\% are Latino (Anonymous, 2013). Urban living has a strong appeal to them and they appear to be more interested in social activities compared with older age cohorts (Anonymous, 2013). Gen $\mathrm{Y}$ are considered digital natives, meaning they have always had the internet. For branded products, they relate to a brand best through a good story about the brand/product and enjoy interacting with some brands on social networks (Anonymous, 2014). Horticulturally, recent evidence suggests that Gen $X$ and Gen $Y$ are quite interested in locally grown and organic fresh produce (Behe et al., 2013; Yue et al., 2012), making them potential buyers for many types of foodproducing plants. For example, "The Foodies" segment identified by Behe et al. (2013) was younger than the other eight segments identified in the study. All members of that consumer segment $(6 \%$ of the total sample) had purchased fruit trees and twothirds of them had purchased herbs and vegetable transplants. Butterfield and Baldwin (2013) reported that $22 \%$ of persons aged 18-34 engaged in vegetable gardening, whereas $15 \%$ engaged in herb gardening.

With an overall decline in plant purchases in a maturing market, a better understanding of several factors may help marketers better understand consumers' use of information in the purchase process. Brand recognition, in particular, may play an important role in the purchase decision and may vary by age cohort. Null hypotheses are outlined in Table 1.

\section{Materials and Methods}

We developed an online survey (institutional review board approval X13-1113e) to better understand the role of age cohort on plant brand recognition and intention to purchase an herb or vegetable transplant. The survey consisted of first viewing 16 images and then answering questions regarding plant brand recognition, awareness, purchases, and use of herb and vegetable transplants. We also collected demographic information about each respondent.

The instrument was developed using Qualtrics (Provo, UT) and was active from 14 May to 16 May 2014. Subjects were recruited by Global Marketing Institute, Inc. (Bellevue, WA) because of their panel quality and pricing. Potential survey respondents were contacted by the vendor and invited to participate. We screened for potential respondents who had made $>0$ plant purchases in the 6 months before the study and attempted to achieve a sample with $\approx 1 / 3$ of the sample in each of three age cohorts: a) born before 1965, which we labeled as Boomers; b) born 1966-85, which we labeled as Gen X; and c) persons born 1986-97, which we

Table 1. Null hypotheses summary table for age cohort influences on brand recognition, brand awareness, and likelihood to buy (LTB) vegetable and herb transplants.

\begin{tabular}{|c|c|c|c|}
\hline $\begin{array}{l}\text { Hypothesis } \\
\text { number }\end{array}$ & Hypothesis & Findings & $\begin{array}{l}\text { Support found in } \\
\text { table no. }\end{array}$ \\
\hline$\overline{\mathrm{H} 1 \mathrm{a}}$ & Baby Boomers will have similar national brand recognition compared with Gen X. & Partial support & 2 \\
\hline $\mathrm{H} 1 \mathrm{~b}$ & Baby Boomers will have similar national brand recognition compared with Gen Y. & Partial support & 2 \\
\hline $\mathrm{H} 2$ & Branded plants will have a similar LTB mean rating compared with unbranded plants. & Not supported & 3 \\
\hline $\mathrm{H} 3 \mathrm{a}$ & Gen X will have a similar LTB branded plants compared with Boomers. & Not supported & 3 \\
\hline $\mathrm{H} 3 \mathrm{~b}$ & Gen Y will have a similar LTB branded plants compared with Boomers. & Not supported & 3 \\
\hline H4 & Consumers who have seen plant brands will be as LTB them as consumers who have not seen them. & Not supported & 4 \\
\hline H5 & Branded plants will have a similar utility score compared with nonbranded or generic plants. & Partial support & 5 \\
\hline H6 & White containers will be similarly preferred to green and yellow containers. & Not supported & 5 \\
\hline H7 & Branded plants will have a similar relative importance score for Boomers and other age cohorts. & Supported & 6 \\
\hline
\end{tabular}



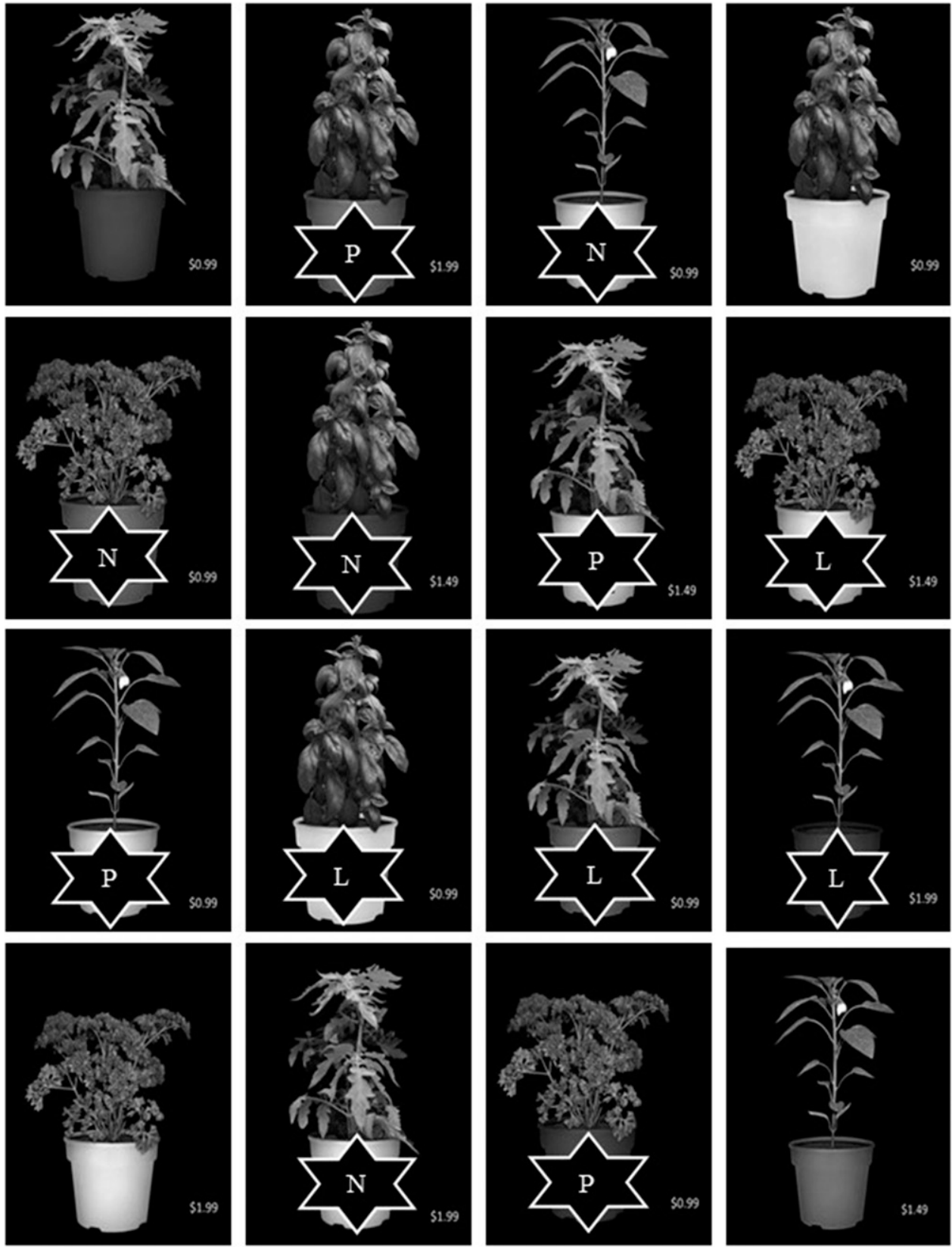

Fig. 1. Conjoint set images (with brands disguised here for anonymity) shown to subjects in an online survey, in order from left to right, top to bottom. Respondents were asked, "How likely would you be to purchase this plant?" The choices were the following: very unlikely, somewhat unlikely, undecided, somewhat likely, and very likely, and treated for analysis as a 1 to 5 Likert scale.

labeled as Gen Y. This division of the total sample would ensure a sufficient number of respondents in each age group to make comparisons between age cohorts.

The images we showed to subjects to determine purchase intention were developed from a conjoint design, which is a statistical method used to determine preferences for products with a given set of attributes (Kuhfeld, 2010). It defines the overall preference for a particular product as the sum of the partworths (also termed utilities) for each product attribute level (Gaasbeck and Bouwman, 1991; Hartigan, 1975). Conjoint analysis has been used to understand the purchase drivers and willingness to pay for attributes and attribute levels for a wide range of horticultural products, including Christmas trees (Behe et al., 2005b), landscapes (Behe et al., 2005a), mixed flowering annual containers (Mason et al., 2008), and sustainable/ eco-friendly plant production (Behe et al., 2010, 2013). For this study, we employed a combination of product attributes and levels that represented a 4 (plant types) $\times 4$ (three national brands and a generic or no brand) $\times 3$ (prices) $\times 3$ (container colors) factorial experiment. Although all 144 combinations could have been presented to subjects, we developed partial factorial design of 16 combinations to retain the ability to assess all attributes in the complete design, but reduce the time investment of each participant (Chrzan and Orme, 2000).
To assess the use of plant brands, we began by selecting, from anecdotal evidence, relatively common transplants for which there may be demand among all age cohorts. Thus we selected vegetable and herb transplants: tomato (Solanum lycopersicum) and pepper (Capsicum annuum) were selected to represent vegetable transplants, whereas parsley (Petroselinum crispum) and basil (Ocimum basilicum) were selected to represent edible herb plants. Container colors were selected based on Whery et al. (2007), whereas price levels $(\$ 0.99, \$ 1.49$, and \$1.99) were chosen based on typical national price reflective of many types of plant outlets of similar products in 2013 . We selected three national plant brands which, 
Table 2. Demographic characteristics of 566 respondents in an online plant branding study. Participants were allowed a no-response answer.

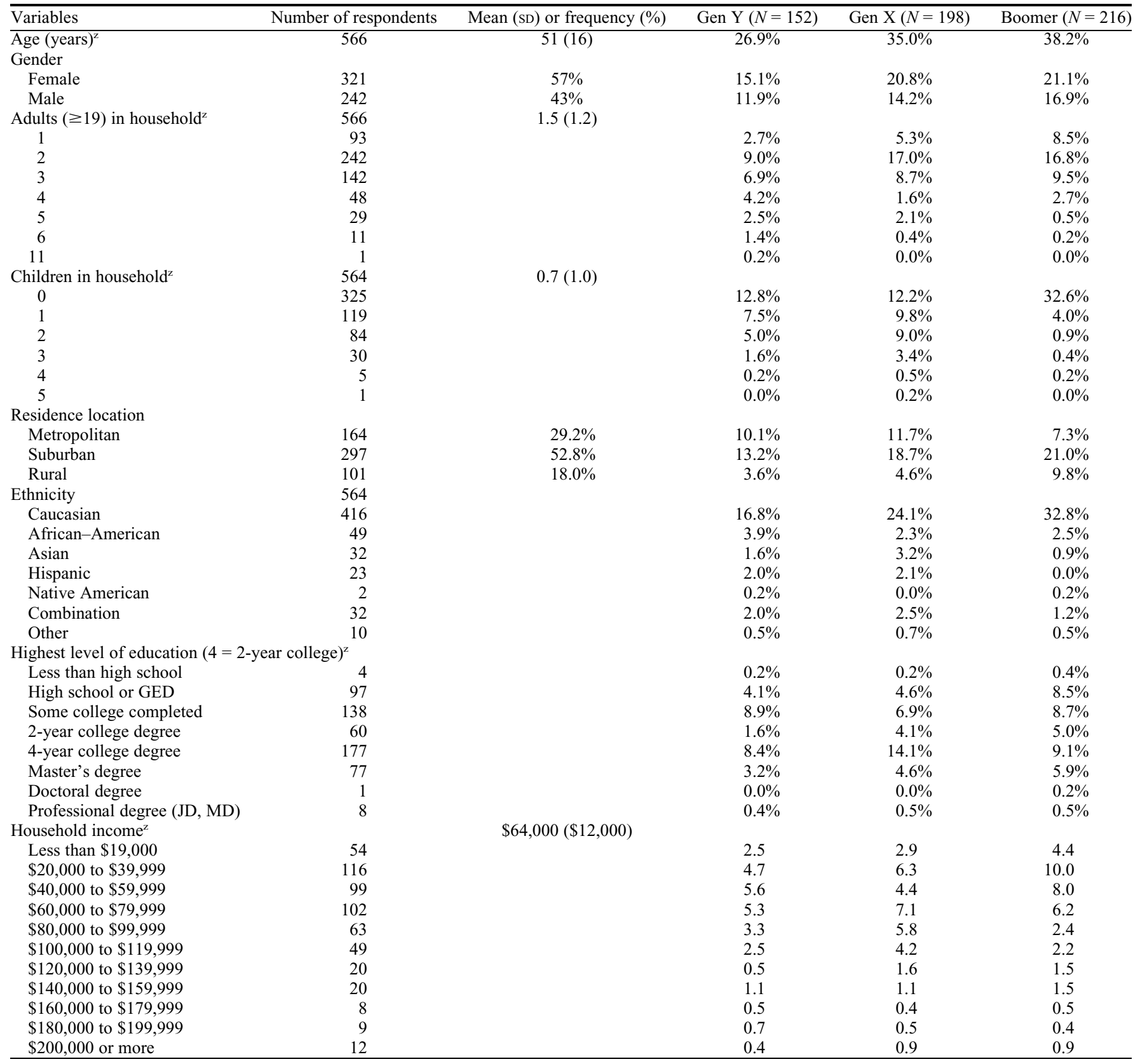

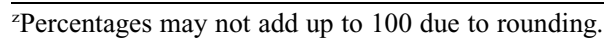

Table 3. Overall and age cohort comparison of brand recognition of three national brands from an online plant branding study.

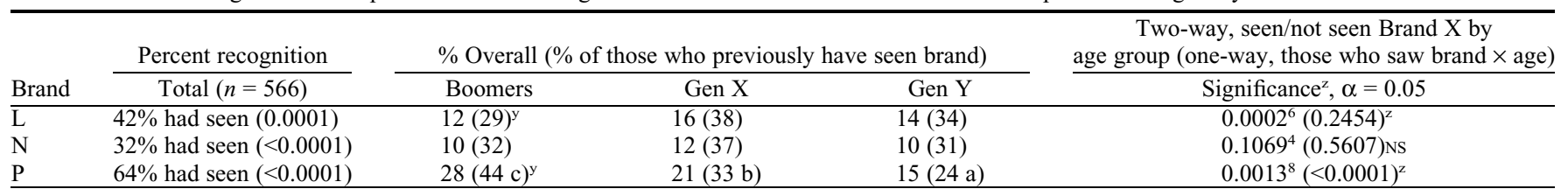

${ }^{\mathrm{z}} \mathrm{A}$ chi-square test was used to test the relationships between the participants' age group and self-reported response to having seen the brand. The analysis was done using the FREQ Procedure in SAS for Windows v 9.4.

${ }^{y}$ Horizontal percentages in () may not total 100 due to rounding.

NS $=$ Nonsignificant.

at the time of the study, had been in existence from 22 to 134 years.

Each image consisted of a picture of a transplant in a $15 \mathrm{~cm}$ container with a price shown in the lower right region of the image (Fig. 1). After photographing the plants against a black background, Adobe Photoshop
(Adobe Systems, San Jose, CA) was used to digitally alter the container color and add brand and price information. Subjects were shown the images and asked to respond verbally to "how likely are you to purchase this plant?" using a 5-point Likert scale. After completing the conjoint portion of the study, brand recognition and awareness were measured by asking subjects if they had previously seen the brand logo shown before the study and how familiar with each plant brand they were. Demographic characteristics were requested in the final portion of the survey. 
Data analysis. For each subject, part-worth utility scores for each level of each attribute, and relative importance values for each attribute were generated using the ordinary least squares (OLS) algorithm for each individual in a metric conjoint analysis. The analysis was done by the TRANSREG Procedure $(\mathrm{METHOD}=$ morals to fit each model individually) in SAS software v. 9.4 (SAS Institute Inc. 2014). The LTB ratings comprised the dependent variable, and the attributes were the independent class variables. Part-worth utilities within each attribute were restricted to a sum of 0 . The OLS algorithm converged for 468 of the 566 dependent variables. Means of attribute utility coefficients and relative importance across respondents by age cohort were analyzed in PROC GLIMMIX for significant differences using Tukey's honestly significant test for conservative pairwise comparisons to avoid Type I errors.

\section{Results and Discussion}

Demographic characteristics. The sample was drawn from the entire United States and consisted of only subjects who had made $>0$ plant purchases. Of the total 566 participants, $27 \%$ were classified as (Gen Y) or born between 1997 and 1986, 35\% were classified as Gen X (born between 1985 and 1966), and $38 \%$ were classified as Boomers (born in 1965 or earlier) (Table 2). Our sample was comprised of $57 \%$ women and $43 \%$ men with a mean of 1.5 adults and 0.7 children in the household. About half lived in a suburban area and $73.8 \%$ were Caucasian. Nearly onethird had attained a 4-year college degree. Median household income was in the $\$ 60,000$ to $\$ 79,999$ range. The demographic characteristics of this sample, with the exception of age, were generally consistent with other samples of plant purchasers or gardeners (Butterfield and Baldwin, 2013; Dennis and Behe, 2007).

Brand awareness and brand recognition. Brand recognition was measured by the percentage of each age cohort who indicated they had seen the national brand logo before participating in the study (Table 3 ). Overall, there was greatest brand recognition for Brand $\mathrm{P}$ (the youngest brand), followed by Brand L then Brand $\mathrm{N}$ (the oldest brand). A higher percentage of Boomers had seen Brand $\mathrm{P}$ compared with Gen Y and Gen X. However, a larger percentage of Gen X and Gen Y had seen Brand L. The percentage of respondents from each age group who had seen Brand $\mathrm{N}$ was similar. Thus, the data partially supported H1a and H1b. Both Brand L and N appear primarily on vegetable and herb transplants, whereas Brand P primarily markets flowering plants. We found that $20.3 \%$ of Boomers had purchased annual plants compared with $6 \%$ of Gen X and 3.4\% of Gen Y $\left(\chi^{2}=190.431\right.$, $P=0.000)$. Having a higher percentage of Boomers who made flowering plant purchases may be one contributing reason for the higher level of brand recognition of the brand appearing primarily on annual plants. Although not available to the researchers, the amount of investment in brand advertising

Table 4. Comparison ${ }^{z}$ of mean likely to buy (LTB) for branded and not branded products overall and by age cohort from an online plant branding study.

\begin{tabular}{llllcc}
\hline Branding & Age group & $N$ & Mean LTB (SE) & F & $P$ \\
\hline Branded & & 6,744 & $3.58(0.04) \mathrm{a}^{y}$ & 16.75 & $<0.0001$ \\
Not branded & & 2,258 & $3.50(0.04) \mathrm{b}$ & & \\
& Gen Y & 2,416 & $3.70(0.05) \mathrm{a}$ & 8.29 & 0.0003 \\
& Gen X & 3,148 & $3.62(0.07) \mathrm{a}$ & & \\
Branded & Boomer & 3,438 & $3.30(0.06) \mathrm{b}$ & & \\
& Gen Y & 1,809 & $3.72(0.08) \mathrm{a}$ & 1.34 & 0.2612 \\
& Gen X & 2,357 & $3.66(0.07) \mathrm{a}$ & & \\
Not branded & Boomer & 2,578 & $3.36(0.07) \mathrm{b}$ & & \\
& Gen Y & 607 & $3.68(0.08) \mathrm{a}$ & & \\
& Gen X & 791 & $3.58(0.08) \mathrm{ab}$ & & \\
& Boomer & 860 & $3.24(0.07) \mathrm{c}$ & & \\
\hline
\end{tabular}

$\overline{{ }^{2} \text { Comparisons for this table were generated using the GLIMMIX Procedure of SAS software, Version } 9.4}$ (SAS Institute, Inc., Cary, NC). The dependent variable was LTB, and the independent variables were branded, age group, and their interaction. Participant was considered a random effect. Mean separation was made using Tukey's adjustment. Of 9056 possible values ( 566 participants and 16 images each), there were 54 missing for a total $N$ of 9002 .

${ }^{y}$ Different letters within each grouping indicate significant differences of means by Tukey's adjustment at $\alpha=0.05$. F and $P$ values are indicated to the right of each grouping.

Table 5. Comparison of mean likely to buy (LTB) for those who previously had seen and not seen each brand by age group from an online plant branding study.

\begin{tabular}{|c|c|c|c|c|c|c|c|c|}
\hline$\overline{\text { Brand }}$ & Age group & Possible $N^{z}$ & Actual $N$ & Mean LTB & & $\overline{\mathrm{SE}}$ & $\bar{F}$ & $P$ \\
\hline \multicolumn{9}{|l|}{ Brand P } \\
\hline Had seen & & 5,840 & 5,807 & 3.50 & $\mathrm{a}$ & 0.03 & 188.21 & $<0.0001$ \\
\hline \multirow[t]{4}{*}{ Had not seen } & & 3,216 & 3,195 & 3.12 & $\mathrm{~b}$ & 0.04 & & \\
\hline & Gen Y & 2,432 & 2,416 & 3.38 & $\mathrm{a}$ & 0.05 & 24.54 & $<0.0001$ \\
\hline & Gen $X$ & 3,168 & 3,148 & 3.38 & $\mathrm{a}$ & 0.04 & & \\
\hline & Boomer & 3,456 & 3,438 & 3.16 & $\mathrm{~b}$ & 0.03 & & \\
\hline \multirow[t]{3}{*}{ Had seen } & Gen Y & 1,376 & 1,366 & 3.61 & $\mathrm{a}$ & 0.05 & 16.01 & $<0.0001$ \\
\hline & Gen X & 1,920 & 1,911 & 3.64 & a & 0.04 & & \\
\hline & Boomer & 2,544 & 2,530 & 3.24 & $\mathrm{~b}$ & 0.03 & & \\
\hline \multirow[t]{3}{*}{ Had not seen } & Gen Y & 1,056 & 1,050 & 3.16 & $\mathrm{bc}$ & 0.05 & & \\
\hline & Gen $X$ & 1,248 & 1,237 & 3.12 & $\mathrm{c}$ & 0.04 & & \\
\hline & Boomer & 912 & 908 & 3.08 & $\mathrm{c}$ & 0.05 & & \\
\hline \multicolumn{9}{|l|}{ Brand L } \\
\hline Had seen & & 3,792 & 3,769 & 3.81 & $\mathrm{a}$ & 0.04 & 828.79 & $<0.0001$ \\
\hline \multirow[t]{4}{*}{ Had not seen } & & 5,264 & 5,233 & 3.05 & $\mathrm{~b}$ & 0.03 & & \\
\hline & Gen Y & 2,432 & 2,416 & 3.44 & $\mathrm{~b}$ & 0.05 & 17.70 & $<0.0001$ \\
\hline & Gen $X$ & 3,168 & 3,148 & 3.52 & $\mathrm{a}$ & 0.03 & & \\
\hline & Boomer & 3,456 & 3,438 & 3.33 & $\mathrm{c}$ & 0.03 & & \\
\hline \multirow[t]{3}{*}{ Had seen } & Gen Y & 1,280 & 1,269 & 3.83 & $\mathrm{~b}$ & 0.05 & 13.83 & $<0.0001$ \\
\hline & Gen X & 1,424 & 1,417 & 3.97 & a & 0.04 & & \\
\hline & Boomer & 1,088 & 1,083 & 3.62 & $\mathrm{c}$ & 0.04 & & \\
\hline \multirow[t]{3}{*}{ Had not seen } & Gen Y & 1,152 & 1,147 & 3.06 & $\mathrm{~d}$ & 0.05 & & \\
\hline & Gen $X$ & 1,744 & 1,731 & 3.07 & $\mathrm{~d}$ & 0.04 & & \\
\hline & Boomer & 2,368 & 2,355 & 3.04 & $\mathrm{~d}$ & 0.03 & & \\
\hline \multicolumn{9}{|l|}{ Brand N } \\
\hline Had seen & & 2,848 & 2,834 & 3.79 & $\mathrm{a}$ & 0.04 & 453.24 & $<0.0001$ \\
\hline \multirow[t]{4}{*}{ Had not seen } & & 6,208 & 6,168 & 3.19 & $\mathrm{~b}$ & 0.03 & & \\
\hline & Gen Y & 2,432 & 2,416 & 3.53 & $\mathrm{a}$ & 0.05 & 22.60 & $<0.0001$ \\
\hline & Gen $X$ & 3,168 & 3,148 & 3.59 & $\mathrm{a}$ & 0.04 & & \\
\hline & Boomer & 3,456 & 3,438 & 3.36 & $\mathrm{~b}$ & 0.03 & & \\
\hline \multirow[t]{3}{*}{ Had seen } & Gen Y & 880 & 874 & 3.79 & $\mathrm{~b}$ & 0.06 & 3.72 & 0.0243 \\
\hline & Gen X & 1,056 & 1,050 & 3.94 & $\mathrm{a}$ & 0.05 & & \\
\hline & Boomer & 912 & 910 & 3.65 & $\mathrm{c}$ & 0.04 & & \\
\hline \multirow[t]{3}{*}{ Had not seen } & Gen Y & 1,552 & 1,542 & 3.28 & $\mathrm{~d}$ & 0.05 & & \\
\hline & Gen $X$ & 2,112 & 2,098 & 3.24 & $\mathrm{~d}$ & 0.04 & & \\
\hline & Boomer & 2,544 & 2,528 & 3.07 & $\mathrm{e}$ & 0.03 & & \\
\hline
\end{tabular}

${ }^{\mathrm{z}}(566$ participants $\times 16$ images each $)-54$ missing values $=9056-54=9002$ actual values.

may also have contributed to the difference in awareness and recognition.

Next, we compared the mean LTB for branded and nonbranded plants by age cohort (Table 4). Overall, branded plants were preferred over unbranded plants, with a higher mean LTB rating even though the plants were digitally identical. This finding rejects the null hypothesis $\mathrm{H} 2$. The goal of a brand is to increase the perceived value, which may be reflected in a higher mean LTB rating. The finding is consistent with several studies on other types of branded products (Dodds and Monroe, 1985; Dodds et al., 1991; Jacoby et al., 1977; Keller, 2013). We also found that mean LTB was higher for the Gen X and Gen Y groups compared with Boomers. This finding did not support the null $\mathrm{H} 3 \mathrm{a}$ and H3b. Consistent with Collart et al. (2010), younger aged consumers were more LTB the 
Table 6. Part-worth scores of plant, price, brand, and container color from a conjoint analysis of $468^{z}$ online respondents, by age cohort, to a plant branding survey. Values are a numerical scoring of consumer preferences among all attributes and levels where a higher number indicates that consumers prefer that particular attribute or level over lower values options. Lower case letters in rows are for generational differences, by attribute, between participants. Upper case letters in columns represent differences between attributes within a generational group. All letters indicate mean separation using Tukey's honestly significant test with $P=0.05$ as a maximum value of significance.

\begin{tabular}{|c|c|c|c|c|c|}
\hline \multirow{2}{*}{ Attribute } & & \multicolumn{4}{|c|}{ Relative importance means (SE) } \\
\hline & & Gen Y $(N=127)$ & Gen $\mathrm{X}(N=160)$ & Boomer $(N=181)$ & Total $(N=468)^{\mathrm{z}}$ \\
\hline$\overline{\text { Plant }}$ & & $39.45(1.89)$ a $\mathrm{A}$ & $42.06(1.69) \mathrm{a} A$ & $45.15(1.59) \mathrm{a} \mathrm{A}$ & $42.22(1) \mathrm{A}$ \\
\hline Price & & $21.08(1.4) \mathrm{b} \mathrm{B}$ & $22.13(1.25) \mathrm{b} \mathrm{B}$ & $22.23(1.17) \mathrm{b} \mathrm{B}$ & $21.81(0.74) \mathrm{B}$ \\
\hline Brand & & $23.29(1.08)$ a B & $21.01(0.97)$ ab B & $19.25(0.91) \mathrm{b} \mathrm{B}$ & $21.18(0.57) \mathrm{B}$ \\
\hline \multicolumn{2}{|c|}{ Container color } & $16.18(0.8)$ a C & $14.79(0.71) \mathrm{ab} C$ & $13.37(0.67) \mathrm{b} \mathrm{C}$ & $14.78(0.42) \mathrm{C}$ \\
\hline & & \multicolumn{4}{|c|}{ Part-worth means (SE) } \\
\hline Attribute & Level & Gen Y $(N=127)$ & Gen $\mathrm{X}(N=160)$ & Boomer $(N=181)$ & Total $(N=468)^{z}$ \\
\hline \multicolumn{6}{|l|}{ Plant } \\
\hline & Basil & $0.21(-0.05) \mathrm{ab} A$ & $0.27(-0.04)$ a A & $0.26(0.04)$ a A & $0.24(-0.02)$ a A \\
\hline & Parsley & $0.01(-0.05)$ bc ABCDE & $0.02(0.05) \mathrm{bc} B C$ & $-0.06(0.05)$ c BCDEF & $-0.01(0.03) \mathrm{b}$ BDE \\
\hline & Pepper & $-0.10(-0.05)$ c DE & $-0.14(0.05)$ c CD & $-0.16(0.04) \mathrm{c} \mathrm{EF}$ & $-0.14(-0.03) \mathrm{c} \mathrm{GH}$ \\
\hline & Tomato & $-0.11(-0.05) \mathrm{c} D E$ & $-0.15(0.04)$ c CD & $-0.04(0.04)$ c BCDEF & $-0.10(0.02) \mathrm{bc}$ DFGH \\
\hline \multicolumn{6}{|l|}{ Price } \\
\hline & $\$ 0.99$ & $0.12(-0.03)$ a $\mathrm{AB}$ & $0.23(0.03)$ a $\mathrm{A}$ & $0.25(0.03)$ a $\mathrm{A}$ & $0.20(-0.02)$ a A \\
\hline & $\$ 1.49$ & $0.00(-0.02) \mathrm{b}$ BCDE & $-0.06(0.02)$ bc C & $-0.06(0.02)$ bc DE & $-0.04(0.01) \mathrm{b}$ CDFG \\
\hline & $\$ 1.99$ & $-0.12(-0.03) \mathrm{cd} E$ & $-0.17(0.03) \mathrm{d} D$ & $-0.19(0.02) \mathrm{d} \mathrm{F}$ & $-0.16(-0.01) \mathrm{c} \mathrm{H}$ \\
\hline \multicolumn{6}{|l|}{ Brand } \\
\hline & Generic & $-0.03(-0.03)$ bcd DE & $-0.08(0.02) \mathrm{cd} C D$ & $-0.01(0.02) \mathrm{d} E F$ & $-0.07(-0.01) \mathrm{c}$ EFG \\
\hline & $\mathrm{L}$ & $-0.06(-0.03) \mathrm{cd} \mathrm{DE}$ & $0.00(0.02)$ abcd BC & $0.09(0.02)$ a B & $0.01(-0.01) \mathrm{ab} \mathrm{BC}$ \\
\hline & $\mathrm{N}$ & $0.02(-0.02)$ abc ABCD & $0.01(0.02)$ abc BC & $-0.04(0.02) \mathrm{cd} C D E$ & $0.00(-0.01) \mathrm{b}$ CD \\
\hline & $\mathrm{P}$ & $0.07(-0.02)$ ab ABCD & $0.07(0.02) \mathrm{ab} B$ & $0.06(0.02) \mathrm{ab} \mathrm{BC}$ & $0.06(-0.01)$ a B \\
\hline \multicolumn{6}{|c|}{ Container color } \\
\hline & Green & $-0.01(0.02) \mathrm{ab} C D$ & $-0.03(0.02) \mathrm{b} \mathrm{C}$ & $-0.05(0.02) \mathrm{b} \mathrm{DE}$ & $-0.03(0.01) \mathrm{b}$ CEF \\
\hline & White & $-0.04(0.02) \mathrm{b} \mathrm{DE}$ & $-0.03(0.02) \mathrm{b} \mathrm{C}$ & $0.00(0.01) \mathrm{ab}$ BCD & $-0.02(0.01) \mathrm{b} C D$ \\
\hline & Yellow & $0.05(0.02)$ a $\mathrm{ABCD}$ & $0.06(0.02) \mathrm{a} \mathrm{B}$ & $0.04(0.02)$ a BC & $0.05(-0.01)$ a B \\
\hline
\end{tabular}

z 98 of the 566 respondents responded with the same purchase intention for all 16 plant images and were therefore excluded from conjoint analysis.

branded plants. Thus it would appear that the national brands studied here did create a perceived difference in the minds of the Gen X and Gen Y subjects of this study.

We then compared the mean LTB score for each brand and each age cohort by whether the participant had seen the brand logo before the study commenced (Table 5). Subjects who had seen the brand logo before the study reported a higher LTB mean score for all three brands study, rejecting the null $\mathrm{H} 4$. This finding was consistent with Hoyer and Brown (1990) who showed that known brands were more likely selected compared with unknown brands. We found an interaction between age and brand recognition, however, the pattern of mean LTB was similar for all three brands in the study. Gen X and Gen Y were more LTB the branded plants they had seen, with Boomers exhibiting a similar reaction but also reporting a lower LTB whether they had seen the brand.

Thus, the brand appeared to be more important and appeared to create product differentiation (although images for branded and unbranded plants were identical) for the younger aged consumers compared with Boomers. Future marketing strategies should include branding as a piece of information used by (especially those younger) consumers to help facilitate their buying decision. Furthermore, we see evidence that brands are being used for plant selection in a manner similar to packaged goods. In the future, branding may help to serve as a part of product differentiation for consumers.

Conjoint analysis. The conjoint model was significant $(\mathrm{F}=231.28, P<0.0001)$ and explained $67 \%$ of the variance in consumer choice of plant using the LTB response (Table 6). Plant type had the highest relative importance, consistent with other studies (Behe et al., 2013; Getter and Behe, 2013; Mason et al., 2008). Brand and price had similar relative importance, which was intermediate to plant type and container color. Lower prices were preferred to higher prices, which can be an indication of logic in consumer LTB ratings and also consistent with other conjoint studies. Calculation of the value for each of the attribute levels followed the same methods as Wollaeger et al. (2015). The range in part worth utility scores was 0.386 units $(0.247$ for basil and -0.139 for pepper), which was equal to $\$ 1$ (equidistant range from low price to mid-price point and high price). Therefore, each unit of utility score equaled $\approx 2.6$ cents. Having no brand on the container detracted $\$ 0.20$ from the value while the national brands added from 0 to $\$ 0.15$ to the perceived value. Brands $\mathrm{N}$ and $\mathrm{P}$ were worth the greatest, whereas Brand $\mathrm{L}$ was worth the same as the unbranded. So, two of the three national brands had a higher perceived value compared with the generic plant, partially supporting $\mathrm{H} 5$ and consistent with Collart et al. (2010) who found that branded products elicited a greater WTP compared with generic plants. Green and white plant containers detracted 8 and 5 cents, respectively, from the perceived value of the product, whereas yellow containers added 13 cents in value. This result did not support the null H6 and was a different finding from that of Whery et al. (2007) who showed that white containers were most preferred and the largest percent of the purchase decision.

We found a few subtle differences in relative importance and utility scores by age cohort, but we did not get a different separation for the age cohorts compared with the overall sample (Table 6). Since Boomer participants exhibited a similar relative importance value for brand compared with Gen X and Gen Y participants, the data did support the null H7.

\section{Conclusions}

Overall, we did find evidence that consumers used brands on herb and vegetable transplants in a manner similar to packaged goods, as was reported in the mainstream marketing literature. Consumers who had seen brands before the study were more LTB them and branded plants generally were perceived to have greater value (for two of three national brands included in this study) although they were digitally identical plants. Thus, brand recognition did influence the purchase decision.

Among the four product attributes tested here, brands and price had a similar impact. The horticulture literature does not provide any other evidence of this to date. Price has had a persistent and relatively high profile in most consumer research. Here, we provide some evidence that branding is, relatively, just as important as price. More work is needed to understand if the branding effect also is observed with other plant categories (e.g., herbaceous perennials, flowering shrubs, evergreen, and deciduous trees).

We also found differences by age cohort. Boomers exhibited less brand recognition with two of the three national brands included in this study. Gen X and Gen Y had a higher mean LTB branded plants compared with Boomers, although branded and unbranded plants were digitally identical. Even despite having seen Brand P more, Boomers were not 
as LTB it compared with the younger age cohorts. These data support evidence to show that brands have a greater influence on younger aged consumers that they do not appear to have on Boomers.

The limitations of this study include the use of nonflowering plant material. Future research should investigate flowering plants to determine similarities and differences. Live plants may be perceived differently from digital images, even though the images were of high quality. More research is needed to better understand the visual cue of branding and who visually examines that and for how long. That information may play a crucial role in our understanding of the use of branding in the purchase decision.

\section{Literature Cited}

American Marketing Association. Dictionary. 2014 27 July 2015. <https://www.ama.org/resources/ Pages/Dictionary.aspx $>$.

Anonymous. 2012. Introducing Boomers: Marketing's most valuable generation. The Nielsen Company and BoomAgers LLC. 9 Feb. 2015. $<$ http://boomagers.com/sites/boomagers/files/ Boomers_-_Marketing\%27s_Most_Valuable_ Generation.pdf $>$.

Anonymous. 2013. American in 2013: Focus on the generations. Urban Land Institute. 9 Feb. 2015. $<$ http://uli.org/research/centers-initiatives/ terwilliger-center-for-housing/research/communitysurvey/s.

Anonymous. 2014. Outlook on the millennial consumer. Hartman group. 9 Feb. 2015. $<$ http://www.hartman-group.com/publications/ reports/outlook-on-the-millennial-consumer-2014>.

Barrow, P. 1994. Marketing to generation X. Can. Manager. 19:23-24.

Behe, B., B. Campbell, J. Dennis, C. Hall, R Lopez, and C. Yue. 2010. Gardening consumer segments vary in eco-practices. HortScience 45:1475-1479.

Behe, B.K., B.L. Campbell, C.R. Hall, H. Khachatryan, J.H. Dennis, and C. Yue. 2013. Consumer preferences for local and sustainable plant production characteristics. HortScience 48:200-208.

Behe, B., J. Hardy, S. Barton, J. Brooker, T. Fernandez, C. Hall, J. Hicks, R. Hinson, P. Knight, R. McNiel, T. Page, B. Rowe, C. Safley, and R. Schutzki. 2005a. Landscape plant material, size, and design sophistication increase perceived home value. J. Environ. Hort. 23(3):127-133.

Behe, B.K., R.M. Walden, M. Duck, B. Cregg, K. Kelley, and R.D. Lineberger. 2005b. Consumer preferences for and cost of production of tabletop Christmas trees. HortScience 40:409-412.

Butterfield, B. and I. Baldwin. 2013. National gardening survey. National Gardening Association, Williston, VT.

Chandon, P., J. Hutchinson, E. Bradlow, and S Young. 2009. Does in-store marketing work? Effects of the number and position of shelf facings on brand attention and evaluation at the point of purchase. J. Mktg. 73(6):1-17.

Chandon, P. and B. Wansink. 2002. When are stockpiled products consumed faster? A conveniencesalience framework of post-purchase consumption incidence and quantity. J. Mktg. Res. 39(3): 321-335.
Chrzan, K. and B. Orme. 2000. An overview and comparison of design strategies for choice-based conjoint analysis. Sawtooth Software Res. Paper Ser., Sequim, WA.

Clement, J., T. Kristensen, and K. Grønhaug. 2013. Understanding consumers' in-store visual perception: The influence of package design features on visual attention. J. Retailing Consum. Serv. 20:234-239.

Collart, A.J., M.A. Palma, and C.R. Hall. 2010 Branding awareness and willingness to pay associated with the Texas Superstar and Earth-Kind brands in Texas. HortScience 45:1226-1231.

Dennis, J.H. and B.K. Behe. 2007. Evaluating the role of ethnicity on gardening purchases and satisfaction. HortScience 42:262-266.

Dodds, W. and K.B. Monroe. 1985. The effect of brand and price information on subjective product evaluations. Adv. Consum. Res. 12(1):85-90.

Dodds, W., K.B. Monroe, and D. Grewal. 1991. Effects of price, brand, and store information on buyers' product evaluations. J. Mktg. Res. 28(3):307-319.

Drèze, X., S.J. Hoch, and M.E. Park. 1993. Shelf management and space elasticity. J. Retailing 70:301-326.

Drucker, P. 2002. The discipline of innovation. Harv. Bus. Rev. Aug:95-102.

Dunn, W. 1993. The baby bust: A generation comes of age. Houghton-Mifflin, New York, NY.

Ehrenberg, A., N. Barnard, and J.A. Scriven. 1997. Differentiation or salience. J. Advert. Res. 37 (6):7-14.

Gaasbeck, A. and V. Bouwman. 1991. Conjoint analysis in market research for horticultural products. Acta Hort.: Hort. Economics Mktg. 295:121-125.

Getter, K.L. and B.K. Behe. 2013. Consumer willingness to purchase Impatiens walleriana alternatives. HortScience 48:1370-1377.

Hall, C., B. Campbell, B. Behe, C. Yue, J. Dennis, and R. Lopez. 2010. The appeal of biodegradable packaging to floral consumers. HortScience 45:583-591.

Hansen, F. 1969. Consumer choice behavior: An experimental approach. J. Mktg. Res. 6:436-443.

Hartigan, J.A. 1975. Clustering algorithms. John Wiley and Sons, New York, NY.

Hodges, A., M. Palma, and C. Hall. 2009. Trade flows and marketing practices within the U.S. nursery industry, 2008. Southern Coop. Ser Bul. 411. ISBN 1-58161-411.

Holmberg, I. 2002. Living trademarks, p. 83-92. In: L. Holger and I. Holmberg (eds.). Identity: Trademarks, logotypes and symbols. National Museum, Raster Forlag, Stockholm, Sweden.

Hoyer, W.D. and S.P. Brown. 1990. Effects of brand awareness on choice for a common, repeatpurchase product. J. Consum. Res. 17(2):141-148.

Jacoby, J., J.C. Olson, and R.A. Haddock. 1971. Price, brand name and product composition characteristics as determinants of perceived quality. J. Appl. Psychol. 55:570-579.

Jacoby, J., D.E. Speller, and C.A. Kohn-Berning. 1974. Brand choice behavior as a function of information load: Replication and extension. J. Consum. Res. 1(1):33-42.

Jacoby, J., G. Szybillo, and J. Busato-Schach. 1977. Information acquisition behavior in brand choice situation. J. Consum. Res. 3:209-216.

Kapferer, J.N. 2012. The new strategic brand management: Advanced insights and strategic thinking. 5th ed. Kogan Page, London.
Kardes, F.R., M.L. Cronley, J.J. Kellaris, and S.S Posavac. 2004. The role of selective information processing in price-quality inference. $\mathrm{J}$. Consum. Res. 31(2):368-374.

Keller, K.L. 2013. Strategic brand management: Building, measuring, and managing brand equity. 4th ed. Pearson Education, New Jersey, NJ.

Kotler, P. and K. Keller. 2009. Marketing management. 13th ed. Pearson Education Ltd., Essex, England.

Krippendorff, K. 2005. The semantic turn: A new foundation for design. CRC Press, Boca Raton, FL

Kuhfeld, W.F. 2010. Marketing research methods in SAS. SAS Institute, Inc., Cary, NC.

Lin, L.Y. and C.S. Chen. 2006. The influence of the country-of-origin image, product knowledge and product involvement on consumer purchase decisions: An empirical study of insurance and catering services in Taiwan. J. Consum. Mktg. 23(5):248-265.

Littrell, M.A., Y.J. Ma, and J. Halepete. 2005. Generation X, baby boomers, and swing: Marketing fair trade apparel. J. Fashion Mktg. Mgt. 9:407-419.

Mason, S., T. Starman, R.D. Lineberger, and B.K Behe. 2008. Consumer preferences for price, color harmony and care information of container gardens. HortScience 43:380-384.

Nedungadi, P. 1990. Recall and consumer consideration sets: Influencing choice without altering brand associations. J. Consum. Res. 17(3): 263-276.

Olson, J.C. and J. Jacoby. 1972. Cue utilization in the quality perception process, p. 167-179. In: M. Venkatesan (ed.). SV-Proceedings of the Third Annual Conference of the Association for Consumer Research. Association for Consumer Research, Chicago, IL.

Rihn, A., C. Yue, B. Behe, and C. Hall. 2012 Generations $\mathrm{X}$ and $\mathrm{Y}$ attitudes towards fresh flowers as gifts: Implications for the floral industry. HortScience 46:736-743.

Roberts, J.A. and C. Manolis. 2000. Baby boomers and busters: An exploratory investigation of attitudes toward marketing, advertising and consumerism. J. Consum. Mktg. 17:481-497.

SAS Institute Inc. 2014. SAS/STAT ${ }^{\circledR} 9.4$ User's Guide, Cary, NC. 9 Feb. 2015. <http://support.sas.com/ documentation/cdl/en/statug/63962/HTML/ default/viewer.htm\#statug_factor_sect006.htm>.

Silvergleit, I. 2004. The floriculture industry: A 10year snapshot. Floral Trend Tracker. 8:1-4.

Simon, H. 1974. How big is a chunk?: By combining data from several experiments, a basic human memory unit can be identified and measured. Science 183:482-488.

Ståhlberg, M. and V. Maila. 2012. Shopper marketing: How to increase purchase decisions at the point of sale. Kogan Limited, Philadelphia, PA.

Whery, R.H., K.M. Kelley, R.D. Berghage, and J.C. Sellmer. 2007. Capturing consumer interests in developing a state plant promotional program. HortScience 42:574-580.

Wollaeger, H.M., K.L. Getter, and B.K. Behe 2015. Consumer preferences for traditional, neonicotinoid-free, bee-friendly, or biological control pest management practices on floriculture crops. HortScience 50:721-732.

Yue, C., J. Dennis, B. Behe, C. Hall, B. Campbell, and R. Lopez. 2012. Investigating consumer preference for organic, local, or sustainable plants. HortScience 46:610-615. 